УДК 633.21:581.12 (292.485) (477.5)

$$
\text { Л. Д. Орлова }
$$

Полтавський національний педагогічний університет ім. В. Г. Короленка

\title{
ІНТЕНСИВНІСТЬ ДИХАННЯ ЛУЧНИХ РОСЛИН ЛІВОБЕРЕЖНОГО ЛІСОСТЕПУ УКРАЇНИ
}

Досліджено інтенсивність дихання лучних представників 14 родин класу Magnoliopsida (Dycotyledores) та двох родин класу Liliopsida (Monocotyledones). Межі коливань показника - від 0,10 до 1,54 мг $\mathrm{CO}_{2} / \Gamma$ сирої ваги за годину. 3'ясовано, що однорічні види мали низькі та середні значення. У ксерофітних видів інтенсивність дихання була низька та середня. Доведено залежність показника від умов навколишнього середовища та фази онтогенезу.

\section{Л. Д. Орлова}

Полтавський национальный педагогический университет им. В. Г. Короленко

\section{ИНТЕНСИВНОСТЬ ДЫХАНИЯ ЛУГОВЫХ РАСТЕНИЙ ЛЕВОБЕРЕЖНОЙ ЛЕСОСТЕПИ УКРАИНЫ}

Изучена интенсивность дыхания луговых представителей 14 семейств класса Magnoliopsida (Dycotyledores) и двух семейств класса Liliopsida (Monocotyledones). Границы колебаний показателя от 0,10 до 1,54 мг $\mathrm{CO}_{2} /$ г сырой массы в час. Установлено, что однолетние виды имели низкие и средние значения. У ксерофитных видов интенсивность дыхания была низкая и средняя. Доказана зависимость от условий среды и фазы онтогенеза.

L. D. Orlova

V. G. Korolenko Poltava National Pedagogical University

\section{RESPIRATORY INTENSITY OF POIC PLANTS OF THE LEFT BANK UKRAINE FOREST-STEPPE}

The intensity of respiration of poic species of Magnoliopsida 14 families (Dycotyledons) class and 2 families of Liliopsida (Monocotyledons) class was studied. The variation limits of that value were from $0.1 \mathrm{up}$ to $1.54 \mathrm{mg} \mathrm{CO} / \mathrm{g}$ of wet weight per hour. The most species had the respiration intensity at a level of $0.21-0.59 \mathrm{mg} \mathrm{CO} / \mathrm{g}$ of wwt per hour. It was found that the annual species had low and medium values as well as the xerophytic species. It depends on the environmental conditions and a phase of ontogeny.

\section{Вступ}

Врожайність дикорослих і сільськогосподарських рослин формується в ході продукційного процесу, основу якого складають одні із найважливіших функцій рослин: фотосинтез, дихання та ріст. Серед факторів продуктивності диханню належить особлива роль. Будучи центральною ланкою обміну речовин, воно бере участь у створенні нових структурних елементів біомаси та забезпеченні їх функціональної цілісності, активному поглинанні елементів мінерального живлення, підтримуванні градієнтів іонів на мембранах, транспорті речовин тощо [5]. 
Найуніверсальнішим показником, який визначається майже в усіх комплексних фізіологічних дослідженнях, $\epsilon$ інтенсивність дихання. Цей показник характеризує швидкість газообміну та виражається кількістю газу, який в даних умовах поглинається або виділяється за одиницю часу одиницею маси рослинного матеріалу.

О. О. Семихатова виділяє три етапи дослідження дихання дикорослих рослин різних місць зростання. Перший етап охоплює першу половину XX століття. Другий включає роботи, проведені з 1950 по 1970 рік. Третій етап починається з 1980 року. На перших етапах в основному опрацьовують ці питання у рослин пустель, жарких місць зростання, гірських районів та півночі. Доведено, що у перших дихання менш інтенсивне, ніж у других, коли виміри проводяться при однаковій температурі. Зміни дихання при втраті води дуже відрізняються навіть у рослин одного екологічного типу. Сучасний період характеризується великою кількістю праць, які встановили, що в різних умовах зростання інтенсивність дихання рослин приблизно однакова, коли іiі визначати при типовій для цих місць середній температурі. Зроблено висновок, що накопичені про дихання дані дозволяють оцінити адаптаційну здатність і адаптованість багатьох рослин до умов середовища i, відповідно, прогнозувати ступінь загрози для цих видів змін умов існування [24].

Класичними в цьому плані є ранні праці О. О. Семихатової [21], яка дослідила водотривку здатність листків у зв'язку зі змінами дихання та кількістю білків. Г. С. Горбунова вивчила зміни фотосинтезу, дихання та деяких інших фізіологічних процесів в онтогенезі рослин у зв'язку з різними умовами середовища [7]. Залежність фотосинтезу та дихання від фотоперіодичних умов у зв'язку з темпами їх розвитку виявив В. С. Цибулько [26]. Аналіз фотосинтетичної активності, мінерального живлення та продуктивності рослин, у тому числі дихання та дихальних ферментів, провів Д. А. Алієв [1]. Детально охарактеризовано особливості дихального газообміну рослин у різних умовах водопостачання, мінерального живлення, щільності тощо; розраховано витрати на дихання та складено баланс органічних речовин у рослин у цих умовах, обговорюється роль дихального газообміну у продукційному процесі в роботі I. А. Куперман, Є. В. Хітрово [13]. М. В. Фролова зі співавторами розглянула екологію луків західної ділянки зони БАМ, у тому числі газообмін, зокрема дихальний [27]. Цікаві спостереження провели Д. М. Гродзинський та О. І. Попович щодо виявлення інтенсивності дихання рослин різних типів стратегії [8]. Монографія О. В. Наумова присвячена виявленню дихального газообміну рослин як фактора продуктивності природних і культурних ценозів степової зони: розглянуто сезонну динаміку, зв'язок дихання з вуглеводним і білковим обміном, вплив умов зростання, проведено порівняльний аналіз участі дихання у продукційному процесі степового фітоценозу й агроценозу [17].

На 48-х Тимірязєвських читаннях О. О. Семихатова представила наслідки дослідження енергетики дихання в нормі та за дії екологічного стресу. Автор розібрала історію формування сучасних уявлень про енергетичну ефективність дихання рослин, навела показники, які характеризують відношення росту та дихання, показала, які з них можуть служити для оцінки енергетичної ефективності процесу упродовж онтогенезу та залежно від екологічного стресу: низької та високої температури, посухи, засолення [23]. Т. К. Головко [6] доведено зв'язок дихання та донорно-акцепторних відносин у рослинах. Г. Д. Леїна показала взаємозв'язок темнового дихання та приросту сухої маси в окремих органах і цілій рослині упродовж репродуктивного періоду [14] та результати вивчення дихання рослин пустельних степів Монголії в період літньої посухи [15]. С. М. Дроздов зі співавторами встановили роль дихання у формуванні терморезистентності рослин [20]. 
О. О. Семихатова стверджує, що антропогенний вплив на природу, можливі глобальні зміни клімату починають загрожувати людству, впливаючи на флору, у тому числі й дикорослу. Тому потрібно передбачати та простежувати зміни дикорослих видів рослин, знайти шляхи їх захисту, виявити та зберегти найвразливіші види, вивчити і по можливості збільшити адаптаційну їх здатність. Велику роль у цьому відіграють дослідження дихання, поряд із з'ясуванням проходження інших процесів, які забезпечують існування рослинного організму [24].

Останнім часом, продовжуючи тенденцію всебічного вивчення окремих представників флори та фітоценозів у цілому, досить багато публікацій присвячено дослідженню дихання сільськогосподарських рослин в умовах водної, піщаної, грунтової культури та на дослідних полях $[3 ; 10 ; 11 ; 18 ; 28 ; 33]$. При цьому 3'ясовувався вплив як окремих факторів, так і цілого комплексу різних умов. Серед них переважають праці зі впливу високої та низької температури, надлишку та нестачі води, газового складу повітря, радіаційного фону та інші.

Разом із тим, публікації щодо дихання лучних рослин в умовах Лівобережного Лісостепу обмежені. Нами раніше це питання з'ясувалося у Echium vulgarum L. як типового представника травостоїв, у тому числі і досліджуваних [19]. Тому основна мета нашої роботи - оцінити інтенсивність дихання лучних рослин у регіоні.

\section{Матеріал і методи дослідження}

Інтенсивність дихання визначалась у представників 16 родин лучної флори. Вони входили до відділу Magnoliophyta (Angiospermae). Серед них 14 родин належали до класу Magnoliopsida (Dycotyledores) та дві родини - до класу Liliopsida (Monocotyledones).

Вивчений показник досліджували методом Бойсена - Ієнсена за кількістю виділеного $\mathrm{CO}_{2}$ [4]. Розрахунки проводили у міліграмах $\mathrm{CO}_{2}$ на грам свіжоподрібненого листя (мг $\mathrm{CO}_{2} /$ г) за годину. Математична обробка результатів проводилась методами варіаційної статистики за Б. О. Доспєховим [9].

\section{Результати та їх обговорення}

Інтенсивність дихання - один із найважливіших показників, що характеризує пристосованість виду, його можливість існування разом з іншими організмами та здатність займати відповідне місце у біоценозі $[8 ; 30 ; 32]$. Дихання відіграє двояку роль у продукційному процесі. 3 одного боку, інтенсивне дихання - необхідна умова енергійного синтезу нових структур і, відповідно, високого темпу накопичення біомаси, з іншого основний шлях (канал) втрат біомаси [13]. За нормальних умов інтенсивність дихання може розглядатися як критерій життєдіяльності рослинного організму [1].

Умови підвищеної чи зниженої активності процесів життєдіяльності рослин, необхідність адаптації до нових чи крайніх умов - причина як додаткових витрат енергії, так іноді і більш або менш тривалого зниження енергетичної ефективності дихання [23]. Виходячи 3 цього, необхідно досліджувати цей показник, який власне дасть можливість 3'ясувати межі коливання, зміни у конкретних видів у різних умовах, а відповідно і можливість їх до пристосувань. Показники досліджених видів коливались від 0,10 до 1,54 мг $\mathrm{CO}_{2} / \Gamma$ сирої ваги за годину. В. В. Кузнєцов та Г. О. Дмитрієва наводять значно ширший інтервал: від 0,02-0,10 до 715,0 мг $\mathrm{CO}_{2} / \Gamma$ сухої ваги за годину [12]. У степових фітоценозах О. В. Наумов дає його на рівні $0,1-8,0$ мг $\mathrm{CO}_{2} /$ г сухої ваги за годину [17].

Середня інтенсивність дихання на рівні різних систематичних груп рослин мінлива (рис.). Найбільше представників на рівні вивчених родин, родів і видів мають 
середню інтенсивність дихання (0,21-0,59 мг $\mathrm{CO}_{2} / \Gamma$ сирої речовини за годину). Невисокі показники мала приблизно однакова кількість рослин у родинах, родах і видах (відповідно 25,0, 29,0, 26,0 \%). Максимальні значення виявились у вивчених представників у межах 25,0-26,0 \%.

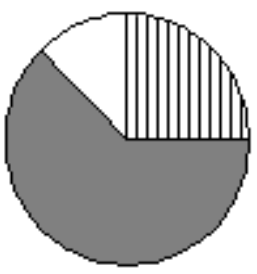

$a$

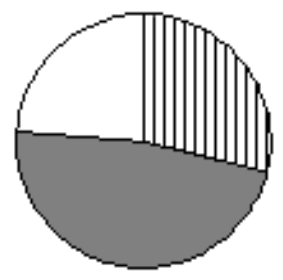

$\sigma$

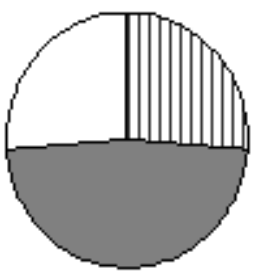

B
प1

$\square 2$

口3

Рис. Групи лучних рослин Лівобережного Лісостепу України

за інтенсивністю дихання в родинах (a), родах (б), видах (в):

$1-0,2$ і менше, $2-0,21-0,59,3-0,6$ і більше мг $\mathrm{CO}_{2} /$ г сирої ваги за годину

Порівняння дихання на рівні представників різних родин показало таку картину. У цілому види Fabaceae мали його більшу інтенсивність, ніж Poaceae, a ті, у свою чергу, більшу, ніж Суреraceae. Х. У. Умаров [25] також указує, що інтенсивність дихання листків представників Fabaceae була вищою, ніж у Роaceae. Він пояснює цю різницю по-перше, більшим вмістом білків у перших, по-друге, більшим накопиченням сухої речовини.

У наших дослідженнях у середньому представники родин різнотрав'я мали показник у межах низьких і середніх величин.

Встановлено, що виявляється залежність показника від біоморфи (за О. Л. Бельгардом [2]). Однорічні види в середньому мали його на рівні низьких значень, а багаторічні, залежно від систематичного положення, - усіх виділених груп.

Аналіз представників залежно від їх відношення до води дозволив виявити таку залежність. Види, які мають більше ксероморфних ознак, мають низьку та середню інтенсивність. Подібні результати отримали й інші автори. Так, за даними О. О. Семихатової, рослини жарких і сухих місць зростання мають дихальну здатність меншу, ніж види помірної зони [22; 23]. Х. У. Умаров [25], аналізуючи роботи I. Є. Знаменського з порівняльного вивчення дихання ксерофітів і мезофітів, вказує, що інтенсивність дихання у перших нижча, ніж у других.

У більшості вивчених видів спостерігається підвищення інтенсивності показника 3 підвищенням температури навколишнього середовища. Ці дослідження продовжують серію робіт у цьому напрямку. Зокрема, праця I. А. Куперман та Є. В. Хитрово [13] належить до перших, широких досліджень із цієї проблеми. У ній відображені основні напрямки вивчення дихання у зв'язку з продукційним процесом - складання балансу сухої речовини на різних етапах і в різних умовах росту рослин; визначення дихання для виявлення оптимальних і крайніх (пошкоджувальних) величин зовнішніх факторів тощо. Основний підхід авторів до проблеми взаємозв'язку дихання та продуктивності екологічний. Вони виявляють залежність величин дихання від основних факторів зовнішнього середовища, наводять кількісні показники дихання як окремих органів і цілих рослин, так посівів. Із останніх потрібно назвати роботу О. Д. Бикова [3], який вказує, що форма температурної кривої дихання далеко не універсальна. Вона визначається, з одного боку, генетичною природою рослинного об'єкта, з іншого - його фізіологічним станом. Г. Д. Леїна [14] вивчила дихання рослин в екстремальних умовах існування і довела, що його інтенсивність можна використовувати для оцінки ре- 
акції ростин на лімітуючі фактори зовнішнього середовища. М. І. Лютова детально дослідила вплив теплового загартовування на фотосинтез і дихання. Вона отримала цікаві результати з цього питання. Зокрема, рівень дихання за дії високих температур у досліджених рослин залежав від виду: він або залишався на одному рівні, або знижувався. Також теплове загартовування рослин викликає збільшення стійкості дихання до дії перегріву [16]. О. О. Семихатова [22] з'ясувала причини високої інтенсивності дихання високогірних рослин. Вона проаналізувала праці попередників із цього питання. Зокрема, щодо особливостей обмінних процесів (азотного живлення, вуглеводного обміну), росту, репараційних реакцій тощо. Висунуто низку положень, які доводять причини підвищеного дихання цієї групи рослин. До них можна віднести збільшення швидкості обміну багатих на енергію фосфорних речовин у зв'язку з необхідністю витрат енергії на відновлення нормального функціонального стану рослин у таких умовах. Вказано особливості температурних адаптацій і акліматизаційного потенціалу при диханні листків деяких видів Ranunculus при нагріванні та охолодженні [31].

Інтенсивність дихання рослин, як і інші фізіологічні процеси, змінюється з віком рослин. Д. А. Алієв указав, що у вивчених культур в онтогенезі інтенсивність дихання має вигляд одновершинної кривої [1]. Він довів, що по мірі старіння показник знижується в усіх частинах рослин. У таких умовах велику роль відіграють мінеральне живлення рослин і температура. Х. У. Умаров [25] наводить наслідки своїх досліджень щодо окремих представників Fabaceae та Poaceae, які свідчать, що рослини в молодому віці мають цей показник набагато вищим, ніж у наступних фазах онтогенезу. Різке зниження інтенсивності дихання у фазі бутонізації він пов'язує з органотвірними процесами, формуванням бутонів і синтетичними перетвореннями речовин, які до них прибувають. Послаблення дихання наприкінці вегетації пояснюється, вочевидь, змінами цитоплазми у старіючих рослин, зокрема зменшенням вмісту води, що відбивається у вигляді затримки росту останніх.

У наших умовах спостерігається подібна тенденція, але вона корегується навколишнім середовищем. Серед них найважливішими були температура та опади. У цілому під час дощу показник знижувався на $10-35 \%$. У цей же період спостерігалося зниження температури (незначне - на $2-3{ }^{\circ} \mathrm{C}$ або досить інтенсивне - до $10^{\circ} \mathrm{C}$, особливо наприкінці травня - на початку червня). Восени залежно від погодних умов показник перебував на рівні значень молодих рослин. Але таку тенденцію виявляли молоді частини рослин (листки), старі та відмираючі мали низькі показники.

О. В. Наумов [17] указує, що дихальний газообмін - важлива ланка кругообігу речовин і потоку енергії в екосистемі. Встановлені відмінності показника дикорослих фітоценозів і агроценозів мають не тільки кількісний, а і якісний характер і повинні враховуватися при створенні високопродуктивних агроекосистем і розробці принципів раціонального використання та охорони природних рослинних ресурсів. Г. Д. Леїна [15] також доводить, що дихання є одним із найважливіших процесів життєдіяльності, що визначає адаптаційні можливості та продуктивність рослин. Саме тому дихання належить до показників, які значною мірою впливають на продуктивність основних типів рослинності, і може бути одним з інструментів для виявлення нових закономірностей при комплексній екологічній оцінці стану фітоценозів, у томі числі й лучних.

\section{Висновки}

Інтенсивність дихання лучних рослин регіону характеризується значною варіабельністю. Найбільше представників на рівні родин, родів і видів мали показник у межах 0,21-0,59 мг $C O_{2} / \Gamma$ сирої ваги за годину. В цілому однорічні види мали його на 
рівні низьких значень. У ксерофітних видів інтенсивність дихання була низькою та середньою. Показник залежить від умов навколишнього середовища та змінюється упродовж онтогенезу.

\section{Бібліографічні посилання}

1. Алиев Д. А. Фотосинтетическая деятельность, минеральное питание и продуктивность растений. - Баку : Элм, 1974. - 335 с.

2. Бельгард А. Л. Лесная растительность юго-востока Украины. - К. : КГУ, 1950. -264 с.

3. Быков О. Д. Температурная зависимость дыхания биологических объектов при непрерывном изменении температуры // Ботан. журн. - 2006. - Т. 91, № 4. - С. 602-614.

4. Викторов Д. П. Практикум по физиологии растений. - Воронеж : Изд-во Воронежского унта, 1991. $-174 \mathrm{c}$.

5. Головко Т. К. Дыхание и продуктивность клевера красного, овса и картофеля // Физиология и биохимия культурных растений. - 1987. - Т. 19, № 4. - С. 334-341.

6. Головко Т. К. Дыхание и донорно-акцепторные отношения в растениях // Газообмен растений в посевах и природных фитоценозах. Тез. докл. Междунар. конф. - Сыктывкар, 1992. C. $18-20$.

7. Горбунова Г. С. Изменение фотосинтеза и некоторых других физиологических процессов в онтогенезе растений в связи с различными условиями среды: Автореф. дисс. ... канд. биол. наук. - Л., 1953. $-18 \mathrm{c}$.

8. Гродзінський Д. М. Інтенсивність дихання в представників рослин різних типів стратегій / Д. М. Гродзінський, О. І. Попович // Укр. ботан. журн. - 1988. - Т. 45, № 3. - С. 21-24.

9. Доспехов Б. А. Методика полевого опыта. - М. : Колос, 1979. - 416 с.

10. Кособрюхов А. А. Влияние периодического повышения концентрации углекислоты в атмосфере на $\mathrm{CO}_{2}$ газообмен и содержание углеводов в листьях огурцов // Вестник Башкирского ун-та. - 2001. - № 2 (1). - С. 47-49.

11. Кошкин Е. И. Дыхание и продуктивность кукурузы при разном радиационном режиме / Е. И. Кошкин, М. В. Моторина, Н. Н. Третьяков // Физиология растений. - 1987. - Т. 34, вип. 2. - С. 276-285.

12. Кузнецов В. В. Физиология растений / В. В. Кузнецов, Г. А. Дмитриева. - М. : Высш. шк., 2006. $-742 \mathrm{c}$.

13. Куперман И. А. Дыхательный газообмен как элемент продукционного процесса растений / И. А. Куперман, Е. В. Хитрово. - Новосибирск : Наука, 1977. - 183 с.

14. Леина Г. Д. Взаимосвязь дыхания и прироста сухой массы у отдельных органов и целого растения Cordamine pratensis (Brassicaceae) в течение репродуктивного периода // Ботан. журн. 1993. - Т. 78, № 2. - С. 39-51.

15. Леина Г. Д. Темновое дыхание растений баглурово-ковылькового сообщества пустынной степи Монголии в период летней засухи // Ботан. журн. - 1994. - Т. 79, № 9. - С. 86-99.

16. Лютова М. И. Влияние тепловой закалки на фотосинтез и дыхание листьев // Ботан. журн. 1962. - Т. 47, № 12. - С. 1761-1774.

17. Наумов А. В. Дыхательный газообмен и продуктивность степных фитоценозов. - Новосибирск : Наука, 1988. -95 с.

18. Обмен $\mathrm{CO}_{2}$ у амаранта при различном водообеспечении / К. Н. Голик, Б. И. Гуляев, А. Я. Зубцова, А. Н. Антонец // Физиология и биохимия культурных растений. - 1993. - Т. 25, № 6. C. $540-545$.

19. Орлова Л. Д. Фізіологічні особливості синяка звичайного (Echium vulgare L.) / Л. Д. Орлова, Т. С. Двірна / Сучасні проблеми біохімії, екології та хімії. Зб. матер. Міжнар. конф., присвяч. 20-річчю біол. ф-ту ЗНУ. - Запоріжжя : ЗНУ, 2007. - С. 73-76.

20. Роль дыхания в формировании терморезистентности растений / С. Н. Дроздов, 3. Ф. Сычева, Э. Г. Попов и др. // Физиология и биохимия культ. растений. - 2005. - Т. 37, № 1. - С. $73-78$.

21. Семихатова О. А. Изучение водоудерживающей способности листьев в связи с изменением дыхания и количеством белка. - Автореф. дисс. ... канд. биол. наук. - Л., 1950. -10 с. 
22. Семихатова О. А. О причине большой интенсивности дыхания высокогорных растений Памира // Ботан. журн. - 1962. - Т. 47, № 5. - С. 636-644.

23. Семихатова О. А. Энергетика дыхания растений в норме и при экологическом стрессе. - Л. : Наука, 1990. - 71 с.

24. Семихатова О. А. Эколого-физиологические исследования темнового дыхания растений: прошлое, настоящее и будущее // Ботан. журн. - 2000. - Т. 85, № 4. - С. 15-30.

25. Умаров Х. У. Изменение интенсивности дыхания клевера красного и тимофеевки луговой // Ботан. журн. - 1962. - Т. 47, № 2. - С. 245-250.

26. Цибулько В. С. Фотосинтез та дихання рослин залежно від фотоперіодичних умов у зв'язку з темпами їх розвитку // Укр. ботан. журн. - 1970. - Т. 27, № 2. - С. 255-258.

27. Экология лугов западного участка зоны БАМ / М. В. Фролова, В. А. Давыдов, Н. А. Журавльов и др. - Новосибирск : Наука, 1986. - 177 с.

28. Юдина О. С. Температурная зависимость дыхания некоторых сортов яровой пшеницы Среднего Поволжья / О. С. Юдина, Г. Д. Леина // Физиология и биохимия культ. растений. 1983. - T. 15, № 4. - C. 315-320.

29. Amthor J. S. The role of maintenance respiration in plant growth // Plant, Cell and Enviroment. 1984. - Vol. 7, N 7. - P. 561-569.

30. Arnon J. Temperature adaptation and acclimation potential of leaf dark respiration in two species of Ranunculus from warm and cold habitats // J. Arnon, C. Körner // Arct. Alp. Res. - 1977. - Vol. 29, N 1. - P. 122-125.

31. Jemm E. W. The respiration of plants and their organs // Plant Physiology. - 1965. -Vol. 4a. P. 231-310.

32. Kallis A. Change of component of dark respiration during the growing period and their relationship with the growing of barley plants / A. Kallis, K. Kull // Produkce biomasy a tvorba vynosy polnich plodin. - Praga, 1977. - P. 81-90.

Надійшла до редколегії 20.10.2010 